\title{
Exploring Sustainability Features and Determinants of Agricultural Insurance Programmes in Low-income Countries
}

\author{
John Bosco Baguri Sumani
}

\begin{abstract}
Agriculture is the main occupation and source of livelihood for the majority of the inhabitants in low-income countries. However, agricultural activities in these countries are confronted with a plethora of challenges, including production and marketing risks. Some of the farmers in lowincome countries have been employing autonomous and planned adaptation strategies, including agricultural insurance contracts to cope with the agricultural risks. Agricultural insurance has been acclaimed to possess enormous potential for managing agricultural risks in low-income countries. This study employed the literature review approach to identify the features and determinants of sustainable agricultural insurance programmes in low-income countries. The study found that the appropriate institutional arrangements, socio-economic and ecological pillars could interact to make agricultural insurance programmes in low-income countries sustainable. Since most low-income countries are still piloting and up scaling their agricultural insurance programmes, I recommend incorporating the institutional, socio-economic and ecological dimensions into the design and implementation of their agricultural insurance schemes.
\end{abstract}

Keywords: Exploring, Sustainability determinants, Agricultural Insurance Programmes, Lowincome Countries

Department of Environment and Resource Studies, Simon Diedong Dombo University of Busines and Integrated Development Studies (SDD-UBIDS), Wa, Ghana, email address: jbbaguri@yahoo.com

Ghana Journal of Geography Vol. 12 (2), 2020 pages 169- 200

https://dx.doi.org/10.4314/gjg.v12i2.8 


\section{Introduction}

Uncertainty is normal and unavoidable in every human endeavor (Scoones and Stirling, 2020), and the agricultural sector is not an exception. Agricultural insurance, therefore, is one of the essential agricultural risks management tools in the world. However, the focus of this paper is on agricultural insurance in low-income countries. Low-income countries are nations with a per capita gross national income (GNI) of less than \$1,026 (World Population Review, 2020). Such countries are also characterized by low human development indices, poverty, high unemployment rates, low life expectancy and environmental degradation. Low-income countries with the above-mentioned characteristics usually require support from donors, international development partners and financial institutions to be able to ameliorate their impoverished circumstances, The World Population Review also refers to low-income countries as underdeveloped or developing countries. Therefore, these terminologies will be used interchangeably in this paper. Some low-income countries listed by the World Bank in early 2020 include Chad, Mali, Burkina Faso, Ethiopia, Afghanistan and Nepal. These countries are mainly peasant farmer-based agricultural economies. Therefore, ensuring sustainable agricultural production in low-income countries requires embracing sustainable agricultural risks management strategies, both indigenous and scientific. Incorporating sustainability issues into discussions on agricultural insurance in contemporary times is spot on because sustainable development itself balances the needs of the present and future generations, be they socio-cultural, economic or ecological.

Formal agricultural insurance (AI) programmes and policies were introduced in the 1800s, especially in America, to help address some of the challenges confronting the agricultural sector (Hoffman, 1900). Index-based AI programmes have also been experimented in some developing countries, including some African countries. Even though some of these schemes died off, with others bedeviled with a plethora of challenges, a few survived and are being up-scaled and expanded (Greatrex, 2015; Sumani, 2018). However, not much has been done in terms of assembling the sustainability traits and determinants of AI in low-income countries. This gap in the AI literature motivated the conduct of this study using a desk study approach. 
I employed a literature review approach in combination with other forms of literature reviews. The use of literature review is informed by the fact that some AI programmes being implemented in both developed and developing countries may be sustainable. However, other governments and stakeholders do not know the lessons and best practices from existing AI programmes. Some researchers (e.g., Hess \& Hazell, 2009; Smith \& Watts, 2009) reported some AI sustainability elements, and yet such studies are scattered in the literature and may be unavailable to some stakeholders. This study has therefore, been designed to use extensive and intensive literature review to identify and condense such AI sustainability features and determinants for practical, policy and academic purposes. For instance, AI programmes and companies can design their products to incorporate these sustainability features and determinants. Governments in lowincome countries could also use the findings of the study to regulate their AI industries. The specific purpose of the literature review is to identify attributes and determinants that can make AI programmes sustainable in vulnerable developing countries.

Agricultural insurance is a contractual agreement between farmers and other agricultural-related stakeholders on the one hand, and insurers on the other hand, whereby the former pays a specified premium in exchange for protection against a particular peril by the latter. The insured peril could be a loss in revenue, crop yields, livestock, fisheries, agricultural equipment, forestry resources or a combination of these losses (Mahul \& Stutley, 2010). Index-based insurance (IBI), on the other hand, denotes payment of compensation to farmers premised on an index that proxies for actual losses (Rao, 2010).

The application of insurance for ex-ante agricultural risks mitigation has been experimented and implemented in some developed countries such as the US and Canada since the 1930s or earlier (Goodwin, 2001; Rao, 2010). Most low-income countries are now either conducting feasibility studies, piloting or up-scaling a special type of AI programmme called index-based agricultural insurance programmes and contracts. This novel insurance scheme is claimed to be suitable for the rural poor and vulnerable smallholder farmers in low-income countries (Barnett \& Mahul, 2007b; Mahul \& Stutley, 2010; Rao, 2010; Greatrex et al., 2015; Sumani, 2018). Even though index-based insurance programmes are classified among the best agricultural risks management tools in 
developing and transitional economies, an evaluation of some piloted schemes for possible upscaling reveals mixed results and reactions (Scoones \& Stirling, 2020). For instance, BinswangerMkhize (2012) and Mobarak (2013) identified high premiums, inadequate demand, low awareness and availability of alternative agricultural risks management strategies as some of the factors militating against up-scaling IBI programmes in low-income countries. Similar studies are replete in the literature. For example, Patt et al. (2009) and Bogale (2015) in their IBI studies in Ethiopia and Banerjee's (2012) research in Nicaragua also unravelled similar findings as those of Binswanger-Mkhize (2012). What is clear is that IBI schemes can help poor smallholders farmers in low-income to address some of their key agricultural risks. However, there are challenges associated with the implementation of IBI programmes in low-income countries, which are being addressed through design and re-design of IBI schemes (Stoppa \& Hess, 2003; Díaz Nieto, Cook, Lundy, \& Fisher, 2006; Osgood et al., 2007; Greatrex et al., 2015; Akter, Krupnik, Rossi, \& Khanam, 2016; Johnson, 2020). What is missing is making index-based programmes and policies sustainable agricultural risks management strategies. This gap is the focus of this study.

This paper is divided into seven sections. The first and second sections discuss agricultural risks and the accompanying risks management strategies respectively. The remaining five sections focus on determinants of sustainable agricultural insurance programmes, a methodology and conceptual framework of the study, a discussion on core themes around sustainability determinants of AI programmes and the conclusions and recommendations. 


\section{Agricultural Risks in Low-income Countries}

The agricultural sector, like other socio-economic enterprises, is faced with a variety of risks and uncertainties. These risks could be biological, hydro-geological, environmental, and socioeconomic ( Piao et al., 2010; Goel, 2013). As an economic sector, these risks could emanate from a chain of agricultural activities including the production phase (Barnett \& Mahul, 2007a), distribution networks, marketing, financial, and post-harvest related losses (Simms et al., 2005; Mills, 2007; Patankar, 2011; Goel, 2013). The agricultural production risks have been mainly caused by weather and climatic perturbations (Smit \& Skinner, 2002); pests and diseases (Ziska \& Runion, 2007); and challenges associated with the acquisition of agro-inputs at the right time and in the right quantities (Goel, 2013). Fresco (2009) also reported agricultural produce being locked up in rural areas in some developing countries due to the poor road network and other related infrastructural challenges.

Some farmers in developing countries are also confronted with demand and price volatilities for their farm produce (Goel, 2013) and lack of access to credit facilities mainly attributable to lack of collateral security (Giné \& Yang, 2009; Goel, 2013). These challenges are reportedly compounded by the adverse impacts of climate variability and change (Lotze-Campen et al., 2012; Stocker et al., 2013). This increases the exposure and vulnerability of farmers, especially smallholder farmers in low-income countries to climate-induced risks and food insecurity conditions (Simms et al., 2005; Füssel \& Klein, 2006; McLeman \& Smit, 2006; Füssel, 2012). This persistent exposure often traps farmers, especially smallholder farmers in a perpetual cycle of poverty if these weather-related disasters are repeated over a long period (Barnett \& Mahul, 2007a; Panda, 2013a). To assist farmers to get out of this vicious cycle of poverty, consumption smoothing strategies are needed including agricultural insurance protection mechanisms.

\section{Agricultural Risks Management Strategies in Low-income Countries}

Agricultural risks management strategies are many and varied. Farmers exposed to the agricultural risks often employ either autonomous or planned adaptation strategies or both to cope with adverse 
impacts of climate variability/change and other associated risks (Adger et al., 2003; Füssel, 2007; Zahniser, Arriola, \& Somwaru, 2010). Autonomous risk mitigation involves the spontaneous application of informal adaptation measures by farmers to cope with the initial agricultural risk including adverse impacts of climate variability and change. These may involve the employment of social capital in its various forms such as donations, remittances, family networks, and mutual support systems for neighbours (Simms, 2005; Sumani, 2008; Sumani, 2018). Other informal agricultural risks management strategies include crop and farm diversification, mixed farming, crop rotation and increasing farms sizes (Simms et al., 2005; Sumani, 2008). Also attested are cultivation of traditional drought and flood-resistant crop varieties (Olubiyo, Hill, \& Webster, 2009; Panda, 2013a); sale of assets and reduction in the frequency, quality, and quantity of meals (Simms et al., 2005; Sumani, 2018; Mahul \& Stutley, 2010). Modern agricultural risks management strategies often employed by farmers to ameliorate adverse climate impacts include improved crop varieties such as drought-resistant, short-maturing and high yielding species; waterefficient crops; savings and loan schemes and AI programmes and policies for marginal farmers in rural areas in low-income countries (Clarke, Mahul, Rao, Verma, 2012).

Even though the above-mentioned informal and scientific mechanisms have been previously engaged to manage agricultural risks, concerns have been raised about uncertainties surrounding their efficacy and sustainability in coping with extreme weather and climate-related events (Smith \& Watts, 2009; Mahul \& Stutley, 2010; Rao, 2010; Johnson, 2020). This is because these risks may be spatially and temporally covariant that they can affect vast geographical areas at the same time (Meze-Hausken, Patt, \& Fritz, 2009; Rao, 2010 ; Scoones \& Stirling, 2020). For instance, entire communities, regions or even nations may be impacted by extreme weather or climatic events like droughts, floods or pestilence. In this case, all farmers could be affected at the same time so that these farmers or group of farmers may not be able to use their existing informal risks management strategies to support one another (Scoones \& Stirling, 2020). Therefore, effective agricultural risks mitigation strategies including AI programmes are required to help vulnerable farmers in low-income countries to adapt to the adverse effects of climate change and other related agricultural uncertainties. However, are current AI programmes and products effective and sustainable agricultural risks mitigation strategies? Johnson (2020) also expressed similar concerns 
Exploring Sustainability Features and Determinants of Agricultural Insurance Programmes in Low-income Countries

in his Book Chapter on Sharing Risks or Proliferation of uncertainties. Insurance, Disaster or Development (p.45). The next section attempts to answer this question.

\section{Sustainability Features of Agricultural Insurance Programmes in Low-Income Countries}

Sustainability is the desired state of every programme or system, and AI schemes are not exceptions. However, it is noteworthy that sustainable development is a complex and everevolving concept (Azapagic \& Perdan, 2000), shrouded in unending arguments about what it means (Jabareen, 2008). While acknowledging the complex and evolving nature of sustainable development in general, and the concept of sustainability in particular, I employ an operational definition of sustainable agricultural insurance programmes in this paper. This working definition anchors on the Brundtland Commission Report's definition of sustainable development (Brundtland,1985); and specifically situated within the conceptual framework for sustainable development (Serageldin, Steer, and Cernea, 1994). The Brundtland Commission Report (1985: 43) defines sustainable development as "development that meets the needs of the present without compromising the ability of future generations to meet their needs." Sustainable programmes or systems are mainly anchored on four main pillars: social, economic, environmental, and institutional domains ( Scoones, 1998; Azapagic \& Perdan, 2000; Carney, 2003).

Operationally, sustainable insurance programmes denote the availability of AI schemes and contracts that meet the aspirations of insurers (returns on investments) and farmers' socioeconomic needs (provision of safety nets and protection) without jeopardizing the ecological resilience and integrity of the physical environment, i.e., maintaining or enhancing the productive capacity of the environment. This translates to AI contracts providing adequate and sustained protection against farmers' agricultural risks with an appreciable level of demand to ensure that investors at least break-even to continue to be in business in an environmentally responsible and ethical manner. Unfortunately, studies specifically focusing on sustainable AI programmes meant for smallholder farmers in developing countries are scarce, in spite of the claim that index-based insurance schemes are the most suitable climate-induced agricultural risk mitigation strategies for 
smallholder farmers in developing countries (Barnett \& Mahul, 2007b; Makauzde \& Miranda, 2008; Rao, 2010; Haruna, 2015).

Much of the research on agricultural insurance in general and index-based insurance in particular, has focused on the robustness and resilience of crop insurance (Hochrainer et al., 2009). Also dicussed are making index insurance attractive to farmers (Patt et al., 2009); protecting financial investments (Clarke et al., 2012; Nunoo \& Acheampong, 2014), and identifying factors motivating supply and demand for agricultural insurance services (Liu, Li, Guo, \& Shan, 2010; Bekkerman, Smith, \& Watts, 2012). Other investigations cover disaster risks reduction potential of crop insurance programmes (Greatrex et al., 2015); farmers' understanding and awareness of index insurance programmes and contracts (Patt et al., 2009; Patt, Suarez, \& Hess, 2010), and the synergy between climate adaptation and mitigation (Mills, 2007; Patt, Suarez, \& Hess, 2010).

Some researchers have also focused on the viability, feasibility, and scalability of crop insurance programmes (Makauzde \& Miranda, 2008; Smith \& Watts, 2009b; McKinley, 2014; Siebert, 2015) and crop insurance programmmes and contracts raising ecological concerns ( Klein \& Maciver, 1999; Phelan et al., 2011; Panda, 2013a; Galaz et al., 2015; Müller \& Kreuer, 2016).

An evaluation of the above studies shows some inherent sustainability attributes as defined by the Brundtland Commission's Report (1985), Serageldin et al., (1994), Azapagic \& Perdan, (2000), and Jabareen (2008). Except for Dahlström, Skea, \& Stahel (2003), Hazell (2010), Hess and Hazell (2009), and Smith and Watts (2009), none of the remaining studies specifically and deliberately explored sustainability domains and features of AI insurance programmes. Concepts and phrases mentioned above (e.g., robustness, sustained demand, effective adaptation and mitigation strategies, risk reduction behaviours, viability, feasibility, scalability and ecological resilience and integrity) are related to the concept of sustainability or sustainable development to some extent. These can further be broadly regrouped into economic, social, environmental, and institutional domains, which can be synthesized to determine comprehensive sustainable systems and programmes. This implies that the studies cited above only partially evaluated the sustainability traits of AI programmes. 
Considering the crucial role of agricultural insurance in promoting farmer well-being and safety nets, especially in low-income countries, I argue that there is the need to intentionally and consciously make insurance programmes and contracts available, accessible, viable, and sustainable. Even though I have so far conducted an extensive literature review, I have yet to come across a study that comprehensively and specifically investigated the sustainability features of AI programmes. However, it is worthy of note that some studies have touched on some aspects of crop insurance sustainability attributes as discussed above, while other researchers just mentioned these features in passing. Those whose studies touched on agricultural insurance sustainability issues, for instance, Hess and Hazell (2009), Smith and Watts (2009) and Hazell (2010), are mainly focused on the social and economic sustainability pillars and attributes almost to the neglect of the ecological and institutional dimensions and indicators. However, this is understandable since these researchers focused their investigations on some aspects of AI programmes and not necessarily, sustainability attributes of AI programmes. This paper has therefore, been crafted to contribute to the on-going discussion on the evolution and development of AI scholarship by attempting to identify and synthesize AI sustainability domains and attributes in low-income countries.

\section{Approach to the Study and the Associated Conceptual Framework}

I employed both systematic and traditional forms of literature reviews to gather the relevant information to be able to achieve my research objectives. Due to the nature and newness of the research topic, I needed to complement information obtained from the systematic literature review strategy with those pieces of data from the traditional forms of literature scan.

With the systematic literature review, I selected the relevant databases. On each of the database, I typed agricultural insurance AND sustainable/sustainability and reviewed the records. Where I did not get enough articles/book chapters from the query, I entered the phrase "agricultural insurance" and read the abstracts to be able select the relevant articles for further and in-depth review. In some instances, I just selected a relevant journal directly and inputted agricultural insurance, reviewed the abstracts to enable me select only relevant articles for further review. 
Since the study aimed at identifying determinants of sustainable AI programmes, I purposively selected and reviewed some specific AI programmes and models in both developed and developing countries to identify what works and what does not work. Some of these AI programmes and models include Goel's (2013) complete agro-financial model, World Food Programme (WFP) and OXFAM America's Climate Change Mitigation Projects in Ethiopia and Senegal. In addition to this are the Index-Based Insurance (IBI) programmes in Australia, Tanzania, Malawi, Senegal, Morocco and McKinley's (2014) experimental research into ecological sustainability and economic viability of cocoa crop insurance based on climate smart agricultural (CSA) practices in Ghana.

This multi-layered approach to literature review encompasses both systematic and traditional literature reviews, with the weaknesses of each being addressed by the strengths of the other. The articles and book chapters reviewed were not also restricted to any spatial and temporal scale due to the nature of the study and its objectives. In searching for attributes that can make AI programmes sustainable, for instance, one needs to glean globally, from the past to the present. Again, this literature review methodology has its weaknesses and strengths. For instance, it involves some amount of subjectivity and possibly personal biases since I am human. However, I tried as much as possible to stay neutral in my choice of information sources. In some instances, I quoted the authors verbatim in order not to dilute the meaning or impose my ideas. In my view, though, the overall strengths outweigh the weaknesses. This approach to the literature gave me ideas that partly inform the Conceptual Framework (Figure 1).

Establishing sustainability traits of AI programmes in low-income countries is an emerging field in the agricultural scholarship. Due to the newness of this field, I have not discovered any single conceptual or theoretical framework that can adequately guide the identification of features of sustainable agricultural insurance schemes in developing countries. However, a synthesis of models, concepts, and ideas informed the design and architecture of the conceptual framework that guided this desk study on exploration of sustainability attributes of AI programmes in lowincome countries (Figure 1). 


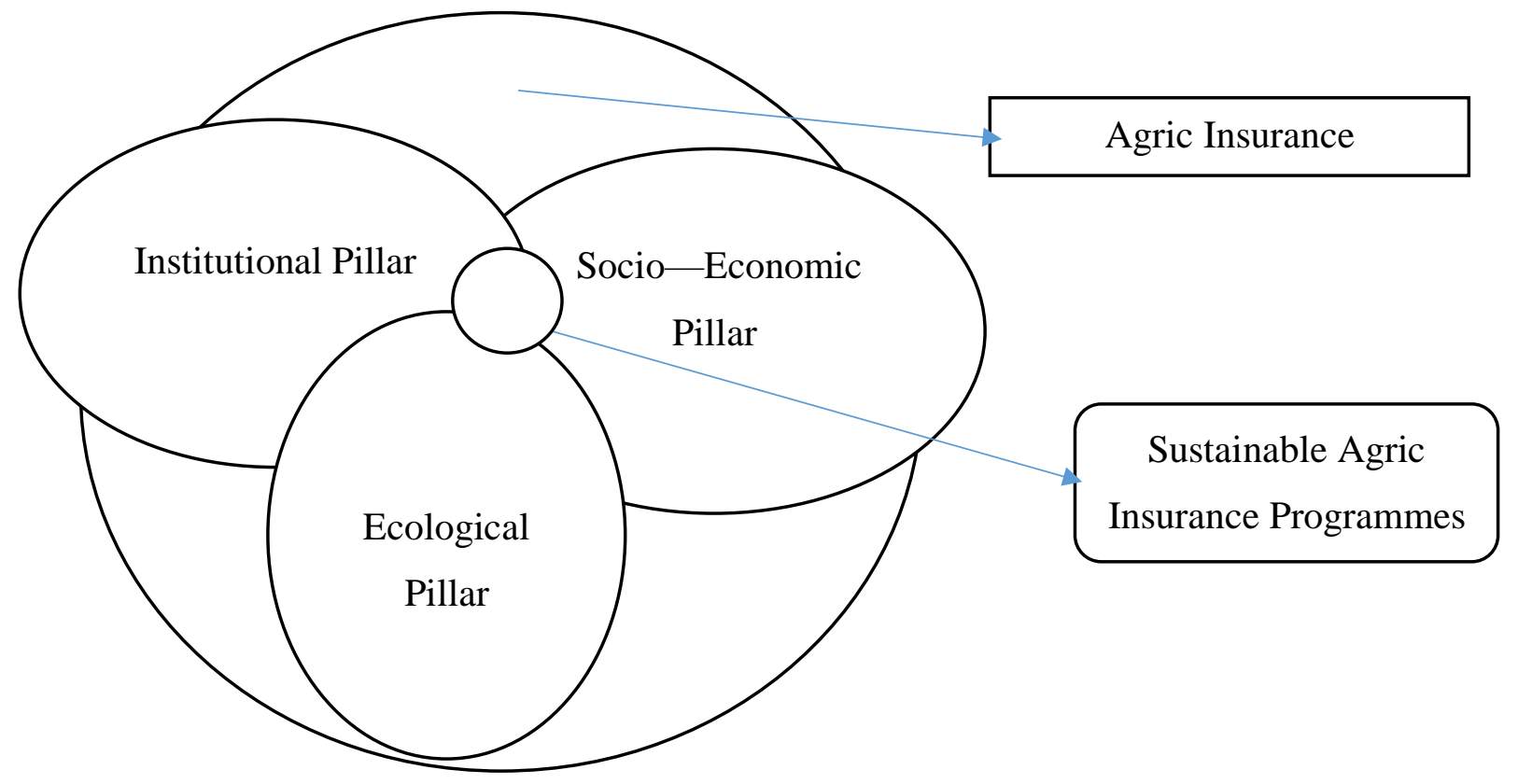

Figure 1: Conceptual Framework for Sustainable Agricultural Programmes for Low-income Countries

The multi-layered literature review approach was used to identify and synthesize sustainability determinants and features of the AI programmes for scholarly, practical and policy purposes in low-income countries. The conceptual framework in figure 1 guided the review of the extant literature and AI programmes. Figure 1 demonstrates that AI programmes and contracts become sustainable when such agricultural risks management strategies incorporate institutional, socioeconomic and ecological pillars into their operational activities. The point of intersection of the socio-economic, ecological and institutional domains (Figure 1) depicts this.

Studies by Azapagic and Perdan (2000), Brundtland Commission's Report on Environment and Development (Brundtland, 1985); Carney (2003); Scoones, (1998), Serageldin et al., (1994), and Sumani (2018 \& 2019) provided a general framework that guides discussions in sustainability development-related issues. These authors identified three pillars of sustainable development; including social, economic and ecological dimensions. Van Oppen's (2001) article: "Insurance: A tool for sustainable development" also reveals how institutions can work to make insurance 
programmes sustainable. The author defines institutions with respect to the insurance industry as comprising governments, private organizations, laws, policies, and social norms.

Goel's (2013) complete agro-financial service framework for emerging economies also informed aspects of the conceptual framework regarding the determinants of sustainable AI programmes and contracts. Goel, in particular identified financial risks, price risks, yield risks and demand and supply risks as some of the key challenges militating against the effective implementation of AI programmes in emerging economies. He, therefore, recommended risks financing, risks control, bundling insurance contracts with agro-inputs and advisory services as well as using agents and technology-based channels to deliver insurance products and services cost-effectively to farmers in rural areas.

Some researchers also reported that piloting of some AI programmes are resulting in ecological degradation and maladaptation in some low-income countries (see Klein \& Maciver, 1999; Phelan et al., 2011; Panda, 2013a; Galaz et al., 2015; Müller \& Kreuer, 2016), thus, increasing the financial liabilities of some insurance companies (Berz, 1999). These authors recommend reversal of this trend during the up-scaling and expansion phase in order to ensure the sustainability of these programmes.

\section{Discussion of Emerging Core Themes of Sustainability Features and Determinants of Agricultural Insurance Programmes in Developing Countries}

The literature review revealed a variety of AI sustainability themes. For purposes of convenient analysis, I classified the sustainability themes into three, informed by the integrated conceptual framework (Figure 1) and the associated pieces of literature reviewed. These sustainability domains include Institutional, Socio-economic and Ecological dimensions as discussed below.

\section{Institutional Arrangements as Determinants of Sustainable AI Programmes}

Van Oppen (2001), while acknowledging the importance of institutions for sustainable development defines institutions as comprising governments, private organizations, laws, policies, and social norms. Despite the importance of these institutional arrangements for ensuring and 
Exploring Sustainability Features and Determinants of Agricultural Insurance Programmes in Low-income Countries

enforcing standards in the insurance industry, they are either not available or only weakly available in most low-income countries (Van Open, 2001).

Gleaning from the literature; institutional, regulatory, technical, financial and design arrangements by insurers, governments, international development agencies (IDAs) and other stakeholders could promote sustainability of AI programmes in developing countries. Sustainability of AI programmes and services begins with the type of insurance programme being implemented. Many researchers, policy-makers, and IDAs claim that index-based insurance programmes are more sustainable than conventional AI programmes (Wenner \& Arias, 2003; Barnett \& Mahul, 2007b; Hellmuth et al., 2009; Patt et al., 2009; Rao, 2010; Skees, 2011; Miranda \& Farrin, 2012; Hossain, 2013). To these authors, compensation emanating from IBI contracts are based on proxies or the insured indices, thus, eliminating or reducing administrative and operational (A\&O) costs, adverse selection, moral hazards, and fraud. This does not only make AI contracts affordable but also reduces the cost of supplying insurance services. The possible increase in demand for AI insurance products because the policies are affordable and the willingness of insurers to provide insurance products and services because of increased demand are prerequisites for AI sustainability.

Another attribute that can make AI programmes sustainable is identifying the appropriate indices that accurately or nearly correlate with yield losses and adequate protection. One of the challenges of index-based insurance schemes is lack of correlation between the actual losses incurred and the indemnities paid (Cell, 2009; Hossain, 2013; Jensen, Barrett, \& Mude, 2014), which Johnson (2020) refers to as the global protection gap, i.e., the difference between total economic loss and insured losses. This challenge is also technically labelled or coined by Miranda (1991) as basis risk in AI circles. Basis risk has been widely blamed for low farmer participation in index-based insurance programmes (Hossain, 2013; Jensen, Mude, \& Barrett, 2014) and lack of trust for insurance products and companies ( Cell, 2009; Patt et al., 2009; Bawakyillenuo et al., 2016; Johnson, 2020). To increase up-take and trust in AI contracts, the variance between actual losses farmers suffer and claims paid has to be eliminated or reduced. Some strategies being employed to achieve this include investments in research (Banerjee \& Berg, 2012; Hossain, 2013), improved agronomic and weather/climate data collection (Cell, 2009; Hossain, 2013). In additiom, other 
strategies used include setting up of more weather stations at high resolution levels (Mahul, 2003; Rao, 2010; Patankar, 2011), development of a combination of indices (composite index) to reflect actual losses incurred (Karlan, Kutsoati, McMillan, \& Udry, 2011; Clarke et al., 2012; Greatrex, 2015). Not only the above, but strategies also available are application of remote sensing and satellite imagery technologies to accurately determine vegetation/or biomass indices with validation from agronomic records and ground truthing (Makauzde \& Miranda, 2008; Makaudze \& Miranda, 2010; Patankar, 2011). Some researchers also recommend that governments should rather use funds meant for ex-post risk management programmes to mop up residual or uncovered losses instead of directly providing ad hoc aid and relief supplies to deal with agricultural-related disasters (Aakre et al., 2010; Porrini \& Schwarze, 2014). According to these researchers, such expost disaster assistance programmes do not only encourage moral hazards and adverse selection behaviors but also compete with existing insurance schemes. This has the tendency to demotivate AI companies from providing ex-ante agricultural risks mitigation services.

Incorporating the appropriate insurance delivery model into the design of the AI insurance programme can also enhance the sustainability of the insurance scheme (Goel, 2013). The various models of AI delivery systems include public/government-owned and operated insurance programmes, public-private partnerships, partner-agent models, direct/full-service models, and mutual/cooperative schemes. According to Reinhard (2012), all these models of insurance delivery systems have their relative strengths and weaknesses. Whereas public-private partnerships arrangements involve governments' support to deliver insurance services to farmers through private insurance companies under special agreements, public/government AI schemes are solely owned and operated by governments through the relevant public sector agencies (Goodwin, 2001; Shields, 2009). In both instances, governments fulfil their contractual obligations by promoting the welfare and safety nets of their citizens in times of yield losses and revenue and price fluctuations (Aakre et al., 2010; Porrini \& Schwarze, 2014). Reinhard (2012) describes partneragent models as arrangements where private insurance companies deliver insurance products to farmers in rural areas through agents already working with farmers, such as, micro-finance institutions (MFIs), cooperatives or NGOs/non-profits. Mutual schemes and cooperatives, on the other hand, are usually community owned and operated by mobilizing savings from their members, granting and/or guaranteeing loans to them, and may also purchase or grant insurance protection 182 
Exploring Sustainability Features and Determinants of Agricultural Insurance Programmes in Low-income Countries

against potential loan default payments and crop failures. Direct sales/full-service insurance companies are centralized private insurance companies that market insurance policies either directly or indirectly through contractual agreements with agents and brokers on either a commission basis, paid salaries or both.

The strengths and weaknesses of each of these models have implications for the effectiveness and sustainability of AI programmes in low-income countries. In my view, the partner/agent and public/private insurance models are the most sustainable arrangements for providing ex-ante agricultural risks mitigation services to farming households in low-income countries. In support of this view, Reinhard (2012), reveals that the partner/agent framework allows well-endowed partner insurance companies to provide upstream legal, technical, financial, and programme/product design structures and functions. It may also have the capacity to contain covariate risk or go into a reinsurance arrangement to do so. The agent in this model also acts as a channel for providing downstream services such as marketing of insurance products, provision of insurance education and other related value-added services such as agro-meteorological and extension services to farmers at the community level (Giné \& Yang, 2009; Goel, 2013). In this partnership, the agents such as MFIs, farmer groups/associations (FG/As), NGOs or cooperatives provide relatively cost-effective and efficient insurance services to farmers. As a medium of communication between the partner insurance company and farmer-clients at the local level, the agent conveys products and other related information to the farmers at the community level and at the same time channel concerns of these farmers to the parent insurance companies upstream. The partner/agent arrangement provides a broader client base and opportunity for interactive feedback. This model, therefore, provides the opportunity for increased demand from economy of scale and promoting transparency and trust in the insurance programmes and products (Patt et al., 2009). In the words of Reinhard (2012: 231):

The partner/agent model can be a 'win-win-win' arrangement. [This arrangement ensures that] the insurer can reach a market that he cannot normally reach on his own; the agent can provide members with better services at a lower cost, and low-income farming households get valuable protection that otherwise would not be accessible to them." 
In spite of the advantages mentioned above, the downstream agents which are usually working to protect the welfare and interest of vulnerable rural community members (as their constituents) may adversely affect the profitability of the partner companies since the agent may be working to promote the welfare of community members than the interest of the insurance company. This may ultimately affect the profitability of the partner company. This challenge needs to be worked on in order to ensure the sustainability of the insurance company for the mutual triple benefit of the partner, agents and the farmers at the local level.

\section{Socio-Economic Features as Determinants of Sustainable Agricultural Insurance Programmes}

The social and economic determinants of sustainable AI programmes are intertwined and intrinsically linked, and as such, discussed together. Economic sustainability of AI programmes focuses on demand and supply considerations. Smith and Watts's (2009) investigation into the feasibility, scalability, and sustainability of index-based AI systems in developing countries found that sustainable AI programmes benefit both farmers and insurers. Hess and Hazell (2009) and Hazell and Hess (2010) AI sustainability-related studies also came out with similar findings. Deducing from the analysis of these authors, the sustainability of index-based AI programmes could be enhanced if insurers provide agricultural risks protection contracts on a broad scale, accompanied by active farmer participation. This is a necessary condition for scalability, but not sufficient to guarantee the sustainability of index-based AI programmes in low-income countries. Sufficient conditions for ensuring sustainable AI programmes, Smith and Watts (2009) maintain, is providing sustained demand for insurance contracts supported by favourable government's regulatory regimes and the ability of the private insurance industry to continue to deliver and manage insurance programmes beyond initial support by IDAs and governments.

Smith and Watts's (2009) framework for determining feasibility, scalability, and sustainability of index programmes has abundant support in the AI literature. For instance, some studies have also assessed sustainability parameters based on willingness to participate in or to pay (WTP) for AI insurance contracts and motivation to invest in these agricultural risks mitigation programmes and infrastructure (Stutley, 2010; Liesivaara \& Myyrä, 2014; Abbas et al., 2015). 
Some researchers have also found that some existing index-based AI programmes in some developing countries are unsustainable based on the economic sustainability criteria spelt out by Hess and Hazell (2009) and Smith and Watts (2009). For instance, Smiths and Watts investigated four IBI programmes in both developed ( 2 in Australia) and developing countries ( 1 each in Tanzania and Morocco) and found that none was sustainable according to the economic sustainability criterion; mainly due to lack of sufficient demand, high premiums, and inadequate protection (basis risk). Similarly, Binswanger-Mkhize (2012) and Siebert's (2015) investigations into the viability and demand for climate-induced index-based insurance contracts also found adverse impacts of climate change to be making AI programmes unsustainable due to the covariate nature of this risk and other natural disasters.

Considering the agricultural risk mitigation potential of index insurance for vulnerable farmers in low-income countries, some proposals have been put forward to make such programmes accessible, affordable, and sustainable. For instance, many index-based AI researchers have recommended innovative ways of reducing $\mathrm{A} \& \mathrm{O}$ costs in order to ensure that contracts are affordable ( Smith \& Watts, 2009; Hazell, 2010; Binswanger-Mkhize, 2012; Goel, 2013). To these authors, A\&O costs can also be reduced by bundling index insurance contracts with other aggregators such as credit-granting institutions, farmer associations, agro-processing entities, and agro-input dealers along the lines of agri-business value chains. They also indicated that some of the aggregators who are already working with the farmers may have the relevant agronomic and climatic data or may collaborate with insurance companies to generate the requisite data. This arrangement has the potential to reduce $\mathrm{A} \& \mathrm{O}$ costs, translating into low premiums, increased demand and profitability of the insurance companies, they revealed. This is a pre-requisite for operating sustainable AI programmes.

Whereas some researchers, practitioners and policymakers think that public and donor agency subsidization of insurance premiums, provision of technical and financial support in addition to reinsurance guarantees may contribute to the sustainability of index insurance programmes, others believe this may rather contribute to the unsustainability of insurance programmes. Those in favour of public support for index-based insurance programmes in developing countries (e.g., Mahul \& 
Stutley, 2010; Clarke et al., 2012; Hossain, 2013; Xu \& Pu, 2014) maintain that these financial and technical support systems will not only make index insurance contracts affordable but will also help deal with systemic risks through reinsurance and reimbursement programmes as being done under the US Federal Crop Insurance Programme (FCIP) (see Shields, 2009). Despite this recognition in the AI literature, the opposing camp (e.g., Goodwin, 2001; McLeman \& Smit, 2006; Nnadi et al., 2013; Panda, 2013a) is against governments' support and subsidization of AI programmes. This group of scholars argue that subsidized insurance programmes and contracts may incentivize farmers not to take ex-ante risk mitigation measures to prevent or reduce the occurrence of some agricultural risks. To them, these support systems often induce farmers to engage in adverse selection, fraud, and moral hazards behaviours as against charging actuarially fair premiums, which often motivate farmers to prevent or reduce agricultural risks proactively, they claim.

Banerjee \& Berg (2012), on the other hand, argue that index-based insurance programmes in lowincome countries require a huge initial financial injection to conduct thorough and adequate pilot studies at the initial stages in order to avoid post-pilot mortality of insurance programmes. To them, public support and subsidization of insurance programmes are pre-requisites for running sustainable AI systems since insurance companies in low-income countries may not be resourceful enough to foot this huge initial design, infrastructure, data acquisition, and research costs. They further added that this support might not be necessary when the insurance schemes stabilize and eventually become self-sufficient, self-financing, and sustainable in the long run.

These schools of thought have some merits and demerits inherent in their arguments. I agree with those arguing for public support for AI programmes to some extent. I particularly identify with Banerjee and Bergs's (2012) argument because the five world-leading AI countries in both developed and developing countries- the US, China, Canada, Spain, and India in that order (Xu \& $\mathrm{Pu}, 2014)$ are subsidizing their AI schemes. These countries have their AI programmes subsidised within the range of $50 \%-80 \%$ of the total premiums or cultivated areas while reimbursing private insurance companies with $\mathrm{A} \& \mathrm{O}$ costs and at the same time providing reinsurance protection (Shields, 2009; Mahul \& Stutley, 2010). A genuine fear has, however, been expressed in the literature that even though low-income countries need initial support for the AI programmes, their 
Exploring Sustainability Features and Determinants of Agricultural Insurance Programmes in Low-income Countries

respective governments may not be able to provide the level of subsidisation being supplied by other richer northern countries (such as the US, Canada and Spain) and still be able to meet their urgent budgetary and poverty reduction commitments (Barnett \& Mahul, 2007b).

While seeing sense in the argument that best insurance programmes in the world are heavily subsidized in both developed and developing nations, I argue that developing countries that place a premium on agricultural risk mitigation will have to prioritize premium subsidization as well as technical and financial support to AI programmes. China and India are also developing countries yet have been able to rank as the $2^{\text {nd }}$ and $5^{\text {th }}$ leading AI countries in the world respectively, with a high level of government support for its AI programmes. These support systems can be weaned off once insurance schemes become self-sustaining and/or sustainable. This view is supported by Banerjee \& Berg (2012).

Socio-cultural factors also have implications for the sustainability of AI schemes in low-income countries. Socio-cultural conditions in this context reflect gender equity, all-inclusiveness and traditional and religious values and norms. Sumani (2018), found that women in Nyankpala, Kazigo and Duori-Guo cultivated crops on their secondary farms (farms owned by women) different from men. At Nyankpala, for instance, women mainly cultivate rice. At Duori-Guo and Kazigo, women were allocated poor lands to cultivate their secondary farms while the males chose fertile agricultural lands for family farms. It was also revealed that males controlled the yields and family finances. This unfair control and distribution of resources has implications for the sustainability of AI programmes. The design of sustainable AI schemes should not only accommodate crops grown by women but should also take into consideration the gender strategic needs and the weak financial position of women in developing countries so that alternative forms of premium payment can be devised. For instance, in-kind forms of premium payment such as the use of livestock or poultry products in-lieu of cash payment. Greatrex et al. (2015) also reported that some poor rural farmers in Ethiopia and Senegal contributed their labour on World Food Programme (WFP) and OXFAM America's Climate Change Mitigation Projects in place of cash premium payment. This initiative was labelled "Labour for insurance (P.8)" or "Insurance for 
work" (P.14)." This innovative form of in-kind premium payment should be promoted in lowincome countries to make AI programmes accessible to all.

\section{Ecological Resilience as an Attribute and Determinant of Sustainable Agricultural Insurance Programmes}

Smallholder farmers in low-income countries like farmers elsewhere mainly depend on natural resources, i.e., environmental and ecological resources for their livelihood activities including farming (Goel, 2013). Therefore, healthy ecological resources such as fertile arable lands and weather/climatic elements, especially rainfall and temperature, are pre-requisites for food security and economic prosperity of farmers. With an ecologically sound arable land, agricultural productivity may increase, ceteris paribus. In this case, yield risks may reduce and insurers' liabilities decreased. This will not only ensure food security, but also promote economic growth, the welfare of farmers and insurers, and ultimately, the sustainability of AI programmes from the medium to the long run.

Despite the crucial role of ecological resilience for sustainable agricultural production, climate change and other environment-related challenges have been reported to be adversely impacting farmers in low-income countries, mainly through droughts, floods and pests infestation (Mendelsohn et al., 2000; Stocker et al., 2013). This is increasing the liabilities of AI companies (Berz, 1999b; Mills, 2007). To help farmers, especially vulnerable farmers in low-income countries adapt to these climatic and other environmental perturbations, some researchers, policymakers, practitioners and development agencies have called for the introduction of index-based AI schemes (Chakravarti, 1920; Halcrow, 1949; Barnett \& Mahul, 2007b). Most developing countries have since piloted index-based insurance programmes and contracts as agricultural risk management strategies which are currently being upscaled and expanded (Cell, 2009; Greatrex et al., 2015; Miranda \& Farrin, 2012).

Some AI evaluative studies have expressed sustainability concerns due to the insurance industry's complicity in ecological degradation and maladaptation ( Klein \& Maciver, 1999; Galaz et al., 2015; Panda, 2013a). This ecological concern has prompted Phelan et al. (2011) and Müller \& 
Kreuer (2016) to specifically research into "Ecological viability or liability? Insurance system responses to climate risk" and "Ecologists should care about insurance, too" respectively. Apart from the concern about ecological deterioration indicated above, Berz (1999b) and Mills (2007, 2009; 2012) revealed that the insurance industry is equally contributing to climate change, and ultimately increasing the financial liability of insurance companies. Other studies also claim that the insurance industry, especially AI programmes also offer the opportunity for simultaneous climate change adaptation and mitigation (Mills, 2007, 2009; Olmstead \& Kleinschmit, 2011; Claassen, 2015). Mills (2012: 1424) in commenting on the role of insurance for climate change mitigation said "where there are risks, there are also opportunities." This implies that agricultural insurance policies can be bundled with climate change mitigation and other agricultural risks management activities as a way of promoting sustainable AI systems, and ultimately, sustainable development.

Both insurers and the insured, especially farmers, can enhance sustainability of the climateinduced AI industry through the engagement of climate and environmentally friendly activities. Dahlström et al. (2003b) indicated that the AI industry could contribute towards creating carbon sinks, carbon sequestration and prevention or reduction of greenhouse gas (GHG) emissions proactively if the political and regulatory systems provide the enabling environment. Some of the climate change mitigation response measures enumerated in the literature include: engaging in climate change awareness creation, designing climate responsive insurance products and services, formulating climate-friendly policy decisions, instituting simultaneous climate change mitigation and adaptation strategies and incorporating climate risk reduction behaviors into contract conditions (Mills, 2007, 2009,2012; Olmstead \& Kleinschmit, 2011; Claassen, 2015). Skees and Collier (2012) also argue that governments and IDAs can connect vulnerable farmers to weather index-based insurance systems and carbon markets through the provision of incentives and application of climate change adaptation and mitigation funds. Through incentives, subsidization of premiums, and application of climate change support funds, insured farmers can be incentivized to engage in sustainable and climate-smart agricultural (CSA) practices such as agroforestry and agro-ecological farming practices. This will not only increase agricultural productivity but also enhance climate change mitigation and ecological health, integrity, and resilience. For instance, 
McKinley's (2014) experimental research into ecological sustainability and economic viability of cocoa crop insurance in Ghana found that the treatment group members (members using climatesmart cocoa (CSC)) farming practices, harvested more cocoa produce per unit area (and generated more revenue), posed less yield and ecological risks as well as cultivated relatively less forest lands than the control group (those who did not employ the CSC practices). Therefore, the sustainability of the AI industry in low-income countries may be enhanced if it incorporates agro-ecological and CSA practices into its programmes and contract designs and operational activities.

It is evident from the preceding discussion that AI programmes can directly contribute to climate change adaptation and mitigation, and indirectly promote the sustainability of the AI programmes and industry in particular and sustainable development in general. For instance, Kelly and Adger (2000) reported that ecological enhancement, whether from AI activities or other sources provides social, economic, and environmental benefits such as increased food production and climate change mitigation. Ecological integrity and resilience that contributes to social and economic benefits re-enforce the centrality of the natural environment for sustainable development.

\section{Limitations of the Study}

This paper has some limitations. These shortcomings include the use of only desk study (literature review) approach to generate the information needed to satisfy my research objectives. An experimental and/or empirical (field-based) study could confirm or contradict some of the findings or provide additional current information. The study was not also based on purely systematic literature review. This implies that personal biases could be introduced in the selection of articles and book chapters for review. I could also be biased or misinterpret the views, ideas and arguments of authors since I am human.

In spite of these limitations, the study findings are valid largely because I tried as much as possible to stay neutral, triangulate sources of information as well as use quotations in order not to dilute the views, ideas and arguments of authors. 


\section{Conclusions and Recommendations}

This paper concludes that Sustainable Agricultural Insurance Programmes are critical for effective agricultural risks management in low-income countries from the medium to the long-term. The literature review reveals that most low-income countries either are conducting feasibility studies, piloting or up scaling their agricultural insurance programmes. The next phase is institutionalizing and promoting sustainability of these AI schemes in order to avoid post-piloting and expansion mortalities so that the full potential of these agricultural risks mitigation strategies can be harnessed.

The literature scan further reveals that sustainability of AI programmes is premised on the interplay between the institutional, socio-economic, and ecological domains. Sustainability of AI programmes in low-income countries demands the institution of the appropriate administrative and regulatory systems and structures to provide the enabling environment. This is particularly so because the existing legislative, regulatory and infrastructural structures and systems in most lowincome countries were not designed with Agricultural Insurance in mind. Reconfiguration of these arrangements will ensure the effective, efficient, and sustainable implementation of the AI programmes.

The second determinant of sustainable AI programmes is the socio-economic domain. This implies that designs of AI programmes should recognize the cultural, traditional and religious attributes of low-income countries. For instance, AI programmes and policies should be designed to target special and strategic gender needs-e.g., cost of insurance, types of crops cultivated and livestock reared are influenced by gender considerations, i.e., by men and women. The literature also indicates that $\mathrm{AI}$ is a business with a profit motive and as such, must engender the willingness of insurers to provide insurance services with ready markets. With participation by farmers and sustained demand, insurers will be willing to provide AI services. The contrary is also true. On the other hand, insurance contracts must meet the expectation of farmers, i.e., granting adequate protection of agricultural risks. Where this is not the case, demand for AI policies will fall, possibly 
leading to losses and folding up of AI companies. By this, the sustainability of AI schemes will be out of sight.

It can also be concluded from the literature surveyed that ecological resilience is a cardinal determinant of sustainable AI systems. This is because sustained production requires ecologically sound arable and grazing lands. This has the potential to reduce yield losses, thus, decreasing the liability of AI companies (i.e., increasing profitability). This can also decrease the A\&O costs, making AI policies available, accessible and affordable. These are necessary conditions for operating sustainable AI programmes and systems.

Index-based insurance programmes, which are premised on the relevant indices, can positively be influenced by ecological resilience. An ecologically sound environment has the potential to improve rainfall patterns and moderate temperatures, i.e., moderating these weather and climatic elements, leading to reduced global warming, and climate variability and climate change. Apart from the possible increase in yields, the improved weather indices may not trigger payouts, thus, reducing compensation and increasing profit margins of AI programmes and companies. In spite of the role of ecological resilience for AI sustainability, some studies are also raising concerns that some AI programmes are rather resulting in ecological degradation and maladaptation in some low-income countries, thus, endangering the sustainability of some AI programmes in some countries.

Despite the sustainability features discussed above, some challenges are still working against making some AI programmes effective agricultural risks management strategies and fully sustainable in some low-income countries. Some of these challenges include low awareness, lack of trust, basis risk, low penetration rate, and some AI activities contributing to environmental degradation and maladaptation. These problems need to be addressed in order to enhance and consolidate the sustainability of AI programmes.

To address the concerns raised above, this paper recommends further research into the designs of AI programmes, especially index-based insurance systems so that the selected indices will reflect actual losses farmers suffer. This will restore confidence and build trust in AI programmes and 
contracts, ultimately leading to increased demand and economies of scale. The AI companies and relevant government agencies should not only involve farmers in the design and implementation of AI programmes and the design of gender-sensitive products but also create awareness about AI among all stakeholders including farmers. This is because agricultural insurance is a complex subject and often leads to misunderstanding and misinterpretation regarding the design of contracts and qualification for compensation. Farmers' involvement in these activities will build confidence and trust in AI systems, programmes, and contracts. I also recommend bundling AI contracts with sound agronomic, climate-smart agricultural and agro-ecological practices to ensure sound ecological resilience and integrity. This has the potential to increase agricultural production and enhance weather and climatic elements, thus, reducing insurance liabilities. Lastly, I recommend government, IDA, donor and bilateral and multi-lateral partner support to AI programmes at the initial stages to enable them to conduct research, build infrastructure, up-scale as well as subsidize premiums. The government and IDA can also directly provide the requisite infrastructure and technical support to AI programmes or companies. All these recommendations have the potential to increase demand and supply of AI systems, programmes, contracts as well as make agricultural risks protection services available, accessible, and affordable. These attributes are pre-requisites for providing sustainable AI systems, programmes, products, and services in low-income countries. 


\section{References}

Aakre, S., Banaszak, I., Mechler, R., Rübbelke, D., Wreford, A., \& Kalirai, H. (2010). Financial adaptation to disaster risk in the European Union. Mitigation and Adaptation Strategies for Global Change, 15(7), 721-736.

Abbas, A., Amjath-Babu, T. S., Kächele, H., \& Müller, K. (2015). Non-structural flood risk mitigation under developing country conditions: an analysis on the determinants of willingness to pay for flood insurance in rural Pakistan. Natural Hazards, 75(3), 2119-2135.

Acheampong, E. N., Ozor, N., \& Owusu, E. S. (2014). Vulnerability assessment of Northern Ghana to climate variability. Climatic Change, 126(1-2), 31.

Adger, W. N., Huq, S., Brown, K., Conway, D., \& Hulme, M. (2003). Adaptation to climate change in the developing world. Progress in Development Studies, 3(3), 179-195.

Akter, S., Brouwer, R., Choudhury, S., \& Aziz, S. (2009). Is there a commercially viable market for crop insurance in rural Bangladesh? Mitigation and Adaptation Strategies for Global Change, 14(3), 215-229.

Azapagic, A., \& Perdan, S. (2000). Indicators of sustainable development for industry: a general framework. Process Safety and Environmental Protection, 78(4), 243-261.

Banerjee, C., \& Berg, E. (2012). Policy for implementation of Index Based Weather Insurance revisited: the case of Nicaragua. St. Louis, United States: Federal Reserve Bank of St Louis.

Barnett, B. J., \& Mahul, O. (2007a). Weather Index Insurance for Agriculture and Rural Areas in Lower-Income Countries. American Journal of Agricultural Economics, 89(5), 1241-1247. doi.org/10.1111/j.1467-8276.2007.01091.x

Barnett, B. J., \& Mahul, O. (2007b). Weather index insurance for agriculture and rural areas in lower-income countries. American Journal of Agricultural Economics, 89(5), 1241-1247.

Bawakyillenuo, S., Yaro, J. A., \& Teye, J. (2016). Exploring the autonomous adaptation strategies to climate change and climate variability in selected villages in the rural northern savannah zone of Ghana. Local Environment, 21(3), 361-382. doi.org/10.1080/13549839.2014.965671

Berz, G. A. (1999b). Catastrophes and climate change: Concerns and possible countermeasures of the insurance industry. Mitigation and Adaptation Strategies for Global Change, 4(3/4), 283293.

Binswanger-Mkhize, H. P. (2012). Is there too much hype about index-based agricultural insurance? Journal of Development Studies, 48(2), 187-200.

Bogale, A. (2015). Weather-indexed insurance: An elusive or achievable adaptation strategy to climate variability and change for smallholder farmers in Ethiopia. Climate and Development, 7(3), 246-256. https://doi.org/10.1080/17565529.2014.934769

Carney, D. (2003). Sustainable livelihoods approaches: progress and possibilities for change. Department for International Development London.

Carson, R., Flores, N. E., \& Hanemann, W. M. (1998). Sequencing and valuing public goods. Journal of Environmental Economics and Management, 36(3), 314-323.

Cell, C. C. (2009). Crop insurance as a risk management strategy in Bangladesh. Department of Environment. Ministry of Environment and Forests. Government of the People's Republic of Bangladesh, Dhaka.

Chakravarti, J. S. (1920). Agricultural insurance: a practical scheme suited to Indian Conditions. Government Press, Bangalore. 
Exploring Sustainability Features and Determinants of Agricultural Insurance Programmes in Low-income Countries

Ciriacy-Wantrup, S. V. (1947). Capital returns from soil-conservation practices. Journal of Farm Economics, 29(4 Part II), 1181-1196

Claassen, R. (2015). 2014 Farm Act Continues Most Previous Trends in Conservation. Amber Waves: The Economics of Food, Farming, Natural Resources, \& Rural America, 1-15.

Clarke, D., Mahul, O., Rao, K. N., \& Verma, N. (2012). Weather based crop insurance in India. World Bank Policy Research Working Paper, (5985).

Dahlström, K., Skea, J., \& Stahel, W. R. (2003a). Innovation, insurability and sustainable development: sharing risk management between insurers and the state. Geneva Papers on Risk and Insurance. Issues and Practice, 394-412.

Edenhofer, O., Wallacher, J., Lotze-Campen, H., Reder, M., Knopf, B., \& Müller, J. (Eds.). (2012). Climate change, justice and sustainability: linking climate and development policy. New York, NY: Springer Science \& Business Media.

Füssel, H.-M. (2007). Adaptation planning for climate change: concepts, assessment approaches, and key lessons. Sustainability Science, 2(2), 265-275.

Füssel, H.-M. (2012a). Vulnerability of coastal populations. In Edenhofer, O., Wallacher, J., Lotze-Campen, H., Reder, M., Knopf, B., \& Müller, J. (Eds.). (2012). Climate change, justice and sustainability: linking climate and development policy. New York, NY: Springer Science \& Business Media.

Füssel, H.-M. (2012b). Vulnerability to climate change and poverty. In Edenhofer, O., Wallacher, J., Lotze-Campen, H., Reder, M., Knopf, B., \& Müller, J. (Eds.). (2012). Climate change, justice and sustainability: linking climate and development policy. New York, NY: Springer Science \& Business Media.

Füssel, H.-M., \& Klein, R. J. (2006). Climate change vulnerability assessments: an evolution of conceptual thinking. Climatic Change, 75(3), 301-329.

Galaz, V., Gars, J., Moberg, F., Nykvist, B., \& Repinski, C. (2015). Why ecologists should care about financial markets. Trends in Ecology \& Evolution, 30(10), 571-580.

Giné, X., \& Yang, D. (2009). Insurance, credit, and technology adoption: Field experimental evidence from Malawi. Journal of Development Economics, 89(1), 1-11.

Goel, K. (2013). A complete agro-financial service framework for emerging economies. The Journal of Risk Finance, 14(5), 490-497.

Goodwin, B. K. (2001). US farm safety nets and the 2000 Agricultural Risk Protection Act. Canadian Journal of Agricultural Economics/Revue Canadienne D'agroeconomie, 49(4), 543555.

Greatrex, H., Hansen, J., Garvin, S., Diro, R., Le Guen, M., Blakeley, S.,... Osgood, D. (2015). Scaling up index insurance for smallholder farmers: Recent evidence and insights. CCAFS Report, CGIAR, Copenhagen.

Hassan, R. M. (2010). Implications of climate change for agricultural sector performance in Africa: policy challenges and research agenda. Journal of African Economies, 19(suppl 2), ii77-ii105.

Hazell, P. B., \& Hess, U. (2010). Drought insurance for agricultural development and food security in dryland areas. Food Security, 2(4), 395-405.

Hazell, P. B. R. (2010). The potential for scale and sustainability in weather index insurance for agriculture and rural livelihoods. International Fund for Agricultural Development. 
Helmuth, M. E., Osgood, D. E., Hess, U., Moorhead, A., Bhojwani, H., Singh, U., ... others. (2009). Index insurance and climate risk: prospects for development and disaster management. In ACIAR Proceedings Series (Australia). Cornell Univ., Ithaca, NY (EUA).

Hess, U., \& Hazell, P. (2009). Sustainability and scalability of index-based insurance for agriculture and rural livelihoods. International Food Policy Research Institute (IFPRI).

Hill, R. V., Hoddinott, J., \& Kumar, N. (2013). Adoption of weather-index insurance: learning from willingness to pay among a panel of households in rural Ethiopia. Agricultural Economics, 44(4-5), 385-398.

Hochrainer, S., Mechler, R., \& Pflug, G. (2009). Climate change and financial adaptation in Africa. Investigating the impact of climate change on the robustness of index-based microinsurance in Malawi. Mitigation and Adaptation Strategies for Global Change, 14(3), 231-250. doi.org/10.1007/s11027-008-9162-5

Hoffman, F. L. (1900). History of the Prudential Insurance Company of America, 1875-1900. Newark, N.J: Prudential Press.

Hoffman, G. W. (1925). Crop insurance-Its recent accomplishments and its possibilities. The Annals of the American Academy of Political and Social Science, 94-120.

Hossain, S. (2013). Problems and prospects of weather index-based crop insurance for rural farmers in Bangladesh. Dev Ctry Stud, 3(12), 208-220.

Jabareen, Y. (2008). A new conceptual framework for sustainable development. Environment, Development and Sustainability, 10(2), 179-192.

Jensen, N. D., Mude, A., \& Barrett, C. B. (2014). How basis risk and spatiotemporal adverse selection influence demand for index insurance: Evidence from northern Kenya. Available at SSRN 2475187. Retrieved from http://papers.ssrn.com/sol3/papers.cfm?abstract_id=2475187.

Johnson, L. (2020). Sharing risks or proliferating uncertainties? Insurance, disaster and development.

In Scoones, I \& Stirling, A. (Eds). Politics of uncertainty: Challenges of transformation (pathways to sustainability series) (pp. 45-57).

Jose, H. D., \& Valluru, R. S. (1997). Insights from the crop insurance reform act of 1994. Agribusiness, 13(6), 587-598.

Karlan, D., Kutsoati, E., McMillan, M., \& Udry, C. (2011). Crop price indemnified loans for farmers: A pilot experiment in rural Ghana. Journal of Risk and Insurance, 78(1), 37-55.

Kelly, P. M., \& Adger, W. N. (2000). Theory and practice in assessing vulnerability to climate change and facilitating adaptation. Climatic Change, 47(4), 325-352

Klein, R. J., \& Maciver, D. C. (1999). Adaptation to climate variability and change: methodological issues. Mitigation and Adaptation Strategies for Global Change, 4(3-4), 189198.

Kunreuther, H., \& others. (1998). Insurability conditions and the supply of coverage. Washington, DC, USA: Joseph Henry Press.

Kurukulasuriya, P., Mendelsohn, R., Hassan, R., Dinar, A., \& others. (2008). A Ricardian analysis of the impact of climate change on African cropland. African Journal of Agricultural and Resource Economics, 2(1), 1-23.

Kurukulasuriya, P., \& Mendelsohn, R. O. (2008). How will climate change shift agro-ecological zones and impact African agriculture? World Bank Policy Research Working Paper Series.

Liesivaara, P., \& Myyrä, S. (2014). Willingness to pay for agricultural crop insurance in the northern EU. Agricultural Finance Review, 74(4), 539-554. 
Exploring Sustainability Features and Determinants of Agricultural Insurance Programmes in Low-income Countries

Liu, B., Li, M., Guo, Y., \& Shan, K. (2010). Analysis of the demand for weather index agricultural insurance on household level in Anhui, China. Agriculture and Agricultural Science Procedia, 1, 179-186. doi.org/10.1016/j.aaspro.2010.09.022

Lotze-Campen, H., Müller, C., Popp, A., \& Füssel, H.-M. (2012). Food security in a changing climate. In Edenhofer, O., Wallacher, J., Lotze-Campen, H., Reder, M., Knopf, B., \& Müller, J. (Eds.). (2012). Climate change, justice and sustainability: linking climate and development policy. New York, NY: Springer Science \& Business Media.

Lotze-Campen, H., \& Popp, A. (2012). Agricultural adaptation options: production technology, insurance, trade. In Edenhofer, O., Wallacher, J., Lotze-Campen, H., Reder, M., Knopf, B., \& Müller, J. (Eds.). (2012). Climate change, justice and sustainability: linking climate and development policy. New York, NY: Springer Science \& Business Media.

Mahul, O., \& Stutley, C. J. (2010). Government support to agricultural insurance: challenges and options for developing countries. World Bank Publications.

Makaudze, E. M., \& Miranda, M. J. (2010). Catastrophic drought insurance based on the

remotely sensed normalised difference vegetation index for smallholder farmers in Zimbabwe. Agrekon, 49(4), 418-432

McKinley, J. D. (2014). The economic viability of cocoa crop insurance in Ghana (M.S.). University of Arkansas, Ann Arbor. Retrieved from ProQuest Dissertations \& Theses Full Text. (1640930291)

McLeman, R., \& Smit, B. (2006). Vulnerability to climate change hazards and risks: crop and flood insurance. Canadian Geographer, 50(2), 217-226. doi.org/10.1111/j.00083658.2006.00136.x

Mendelsohn, R., Dinar, A., \& Dalfelt, A. (2000). Climate change impacts on African agriculture.

Preliminary analysis prepared for the World Bank, Washington, District of Columbia, 25.

Meze-Hausken, E., Patt, A., \& Fritz, S. (2009). Reducing climate risk for micro-insurance providers in Africa: a case study of Ethiopia. Global Environmental Change, 19(1), 66-73.

Mills, E. (2007). Synergisms between climate change mitigation and adaptation: an insurance perspective. Mitigation and Adaptation Strategies for Global Change, 12(5), 809-842.

Mills, E. (2009). A global review of insurance industry responses to climate change. The Geneva Papers on Risk and Insurance-Issues and Practice, 34(3), 323-359.

Mills, E. (2012). The greening of insurance. Science, 338(6113), 1424-1425.

Miranda, M. J., \& Farrin, K. (2012). Index Insurance for Developing Countries. Applied Economic Perspectives \& Policy, 34(3), 391-427.

Mobarak, A. M., \& Rosenzweig, M. R. (2013). Informal risk sharing, index insurance, and risk taking in developing countries. The American Economic Review, 103(3), 375-380.

Moellendorf, D. (2015). Climate Change Justice: Climate Change Justice. Philosophy Compass, 10(3), 173-186. http://doi.org/10.1111/phc3.12201

Moser, S. C. (2012). Adaptation, mitigation, and their disharmonious discontents: an essay.

Climatic Change, 111(2), 165-175.

Müller, B., \& Kreuer, D. (2016). Ecologists should care about insurance, too. Trends in Ecology \& Evolution, 31(1), 1.

Myjoyonline.com. (n.d.). Ghana News - Drought destroys 200-hectare orange, palm oil farms. Retrieved March 3, 2016, from http://www.myjoyonline.com/news/2016/March-2nd/droughtdestroys-200-hectare-orange-palm-oil-farms.php 
Nnadi, F. N., Chikaire, J., Echetama, J. A., Ihenacho, R. A., Umunnakwe, P. C., \& Utazi, C. O. (2013). Agricultural insurance: A strategic tool for climate change adaptation in the agricultural sector. Net Journal of Agricultural Science, 1(1), 1-9.

Nunoo, J., \& Acheampong, B. N. (2014). Protecting financial investment: agriculture insurance in Ghana. Agricultural Finance Review, 74(2), 236-247.

Nyong, A., Adesina, F., \& Elasha, B. O. (2007). The value of indigenous knowledge in climate change mitigation and adaptation strategies in the African Sahel. Mitigation and Adaptation Strategies for Global Change, 12(5), 787-797.

Olmstead, J., \& Kleinschmit, J. (2011). A Risky Proposition. Institute for Agriculture and Trade

Policy.

Panda, A. (2013a). Climate Variability and the Role of Access to crop insurance as a SocialProtection Measure: Insights from India. Development Policy Review, 31(s2), o57-o73.

Parry, M. ., Rosenzweig, C., Iglesias, A., Livermore, M., \& Fischer, G. (2004). Effects of climate change on global food production under SRES emissions and socio-economic scenarios. Global Environmental Change, 14(1), 53-67. doi.org/10.1016/j.gloenvcha.2003.10.008

Patankar, M. (2011). Comprehensive risk cover through remote sensing techniques in agriculture insurance for developing countries: A pilot project. ILO Microinsurance Innovation Facility Research Paper.

Patt, A., Peterson, N., Carter, M., Velez, M., Hess, U., \& Suarez, P. (2009). Making index insurance attractive to farmers. Mitigation and Adaptation Strategies for Global Change, 14(8), 737-753. doi.org/10.1007/s11027-009-9196-3

Patt, A., Suarez, P., \& Hess, U. (2010). How do small-holder farmers understand insurance, and how much do they want it? Evidence from Africa. Global Environmental Change Part A: Human \& Policy Dimensions, 20(1), 153-161. doi.org/10.1016/j.gloenvcha.2009.10.007

Phelan, L., Taplin, R., Henderson-Sellers, A., \& Albrecht, G. (2011). Ecological viability or liability? Insurance system responses to climate risk. Environmental Policy and Governance, 21(2), 112-130.

Porrini, D., \& Schwarze, R. (2014). Insurance models and European climate change policies: an assessment. European Journal of Law and Economics, 38(1), 7-28.

Rao, K. N. (2010). Index based crop insurance. Agriculture and Agricultural Science Procedia, 1, 193-203.

Reinhard, D. (2012). Potentials and limitations of microinsurance for protecting the poor. In Edenhofer, O., Wallacher, J., Lotze-Campen, H., Reder, M., Knopf, B., \& Müller, J. (Eds.). (2012). Climate change, justice and sustainability: linking climate and development policy. New York, NY: Springer Science \& Business Media.

Rosenzweig, C., Parry, M. L., \& others. (1994). Potential impact of climate change on world food supply. Nature, 367(6459), 133-138.

Scoones, I. (1998). Sustainable rural livelihoods: a framework for analysis. Retrieved from http://mobile.opendocs.ids.ac.uk/opendocs/handle/123456789/3390

Scoones, I., \& Stirling, A. (Eds). (2020). Uncertainty and the politics of transformation. In Scoones, I \&

Stirling, A. (Eds). Politics of uncertainty: Challenges of transformation (pathways to sustainability series).to sustainability) (pp. 1-30). STEPS Center, University of Sussex: Routledge.

Serageldin, I., Steer, A. D., \& Cernea, M. M. (1994). Making development sustainable: from concepts to action (Vol. 2). World Bank Publications. 
Sherrick, B. J., Schnitkey, G. D., Ellinger, P. N., Barry, P. J., \& Wansink, B. (2003). Farmers' preferences for crop insurance attributes. Review of Agricultural Economics, 25(2), 415-429.

Shields, D. A. (2009). Federal crop insurance: Background and issues. Congressional Research Service, Library of Congress.

Siebert, A. (2015). Assessing the viability of index insurance as an adaptation tool in a changing climate context: Case Study in the West African Sahel. (Doctoral Dissertation, Rutgers, the State University of New Jersey - New Brunswick, Ann Arbor. Retrieved from ProQuest Dissertations $\&$ Theses Full Text. (1676475909)

Simms, A., Reid, H., \& others. (2005). Africa: Up in Smoke? Oxfam. Retrieved from https://books.google.com/books

Skees, J. R., \& Collier, B. (2012). The roles of weather insurance and the carbon market.

In Greening the Financial Sector (pp. 111-164). Springer Berlin Heidelberg.

Smit, B., \& Pilifosova, O. (2003). Adaptation to climate change in the context of sustainable development and equity. Sustainable Development, 8(9), 9.

Smith, V. H., Goodwin, B. K., \& Brown, J. (2010). Private and public roles in providing agricultural insurance in the United States. Public Insurance and Private Markets, 173-210.

Smith, V., \& Watts, M. (2009). Index based agricultural insurance in developing countries: Feasibility, scalability and sustainability. Bill \& Melinda Gates Foundation.

Solomon, S. (2009). Climate Change 2007: The Physical Science Basis. Taylor \& Francis. tandfonline.com/doi/pdf/10.1080/03736245.2009.9725337

Stern, N. (2007). The economics of climate change: the Stern review. Cambridge University press.

Stocker, T. F., Qin, D., Plattner, G. K., Tignor, M., Allen, S. K., Boschung, J., ... Midgley, B. M. (2013). IPCC, 2013: climate change 2013: the physical science basis. Contribution of working group I to the fifth assessment report of the intergovernmental panel on climate change.

Stutley, C. (2010). Innovative Insurance Products for the Adaptation to Climate Change Project Ghana. Innovative Insurance Products for the Adaptation to Climate Change Project Ghana.

Sumani, J. B. B. (2018). Exploring Perceptions of the Potential of Agricultural Insurance for Crop Risks Management Among Smallholder Farmers in Northern Ghana [Ph.D., Antioch University].

http://search.proquest.com/pqdtglobal/docview/2081243207/abstract/A93E693ED7BD4759P

$\mathrm{Q} / 1$

Sumani, J. B. B. (2019). Possible Environmental and Socio-economic Ramifications of Sand and Gravel Winning in Danko, Upper West Region of Ghana. Ghana Journal of Geography, 11(2), 27-51.

Sumani, J.B.B. (2008). The impact of climate change on human migration in the Upper West

Region: The case of Nadowli District (Master of Science Thesis, Antioch University New England).

Tubiello, F. (2012). Climate change adaptation and mitigation: challenges and opportunities in the food sector. Natural Resources Management and Environment Department, FAO: Rome, Italy. Van Dyke, F. (2008). Conservation biology: foundations, concepts, applications. New York, NY: McGraw-Hill Companies, Inc.

Van Oppen, C. (2001). Insurance: a tool for sustainable development. Insurance Research and Practice, 16(1), 47-60. 
Varian, H. R. (1992). Microeconomic analysis. Retrieved from http://ecsocman.hse.ru/text/19187279/

Integrating mitigation and adaptation-possible responses to global climate change. Environment, 45(5), 28-38.

XU, J., \& Pu, L. (2014). Crop insurance, premium subsidy and agricultural output. Journal of Integrative Agriculture, 13(11), 2537-2545.

World Population Review (2020). Low Income Countries Population. Retrieved 2020-02-15, from http://worldpopulationreview.com/countries/low-income-countries/

Yohe, G., \& Strzepek, K. (2007). Adaptation and mitigation as complementary tools for reducing the risk of climate impacts. Mitigation and Adaptation Strategies for Global Change, 12(5), 727-739.

Zahniser, S., Arriola, C., \& Somwaru, A. (2010). The European Union's framework for climate change adaptation: Implications of agriculture's adaptation through sustained yield growth. International Agricultural Trade Research Consortium. 